\title{
Space-time clustering and associated risk factors of pulmonary tuberculosis in southwest China
}

\author{
Li Huang 1,2,3,4,5, Eniola Michael Abe 2,3,4,5 Xin-Xu Li ${ }^{6}$, Robert Bergquist ${ }^{7}$, Lin Xu' ${ }^{1}$, Jing-Bo Xue ${ }^{2,3,4,5}$, Yao Ruan²,3,4, \\ Chun-Li CaO $2,3,4,5$ and Shi-Zhu Li $2,3,4,5^{*}$
}

\begin{abstract}
Background: Pulmonary tuberculosis (PTB,both smear positive and smear negative) is an airborne infectious disease of major public health concern in China and other parts of the world where PTB endemicity is reported. This study aims at identifying PTB spatio-temporal clusters and associated risk factors in Zhaotong prefecture-level city, located in southwest China, where the PTB notification rate was higher than the average rate in the entire country.

Methods: Space-time scan statistics were carried out using PTB registered data in the nationwide TB online registration system from 2011 to 2015, to identify spatial clusters. PTB patients diagnosed between October 2015 and February 2016 were selected and a structured questionnaire was administered to collect a set of variables that includes socio-economic status, behavioural characteristics, local environmental and biological characteristics. Based on the discovery of detailed town-level spatio-temporal PTB clusters, we divided selected subjects into two groups including the cases that resides within and outside identified clusters. Then, logistic regression analysis was applied comparing the results of variables between the two groups.
\end{abstract}

Results: A total of 1508 subjects consented and participated in the survey. Clusters for PTB cases were identified in 38 towns distributed over south-western Zhaotong. Logistic regression analysis showed that history of chronic bronchitis $(O R=3.683,95 \% \mathrm{Cl}: 2.180-6.223)$, living in an urban area $(O R=5.876,95 \% \mathrm{Cl}: 2.381-14.502)$ and using coal as the main fuel $(O R=9.356,95 \% \mathrm{Cl}: 5.620-15.576)$ were independently associated with clustering. While, not smoking $(O R=0.340$, 95\% Cl: $0.137-0.843$ ) is the protection factor of spatial clustering.

Conclusions: We found PTB specially clustered in south-western Zhaotong. The strong associated factors influencing the PTB spatial cluster including: the history of chronic bronchitis, living in the urban area, smoking and the use of coal as the main fuel for cooking and heating. Therefore, efforts should be made to curtail these associated factors.

Keywords: Pulmonary tuberculosis, Spatio-temporal clustering, Regression analysis method, Risk factors, China

\section{Multilingual abstracts}

Please see Additional file 1 for translations of the abstract into the five official working languages of the United Nations.

\section{Background}

With an estimated 9.6 million infected people and 1.5 million deaths globally in 2014, tuberculosis (TB), caused by

\footnotetext{
* Correspondence: stoneli1130@126.com

${ }^{2}$ National Institute of Parasitic Diseases, Chinese Center for Disease Control and Prevention, Ruijing Er road 207, Shanghai 200025, China

${ }^{3}$ National Research Center for Tropical Disease, Shanghai, China

Full list of author information is available at the end of the article
}

Mycobacterium tuberculosis, poses a serious challenge to global health [1]. Pulmonary tuberculosisis ranked second among the high-mortality infectious diseases and the World Health Organization (WHO) estimated 930 000, 1 million and 2.2 million new TB cases for China, Indonesia and India, respectively in 2015 [2]. Despite decreasing trend in incidence and mortality between 1990 and 2015, $\mathrm{TB}$ remains a serious threat to public health and social development in China [3, 4].

The burden of TB is particularly high across various regions of Yunnan, a mountainous and ethnically diverse province located in south-western China with poor economy. Pulmonary tuberculosis (PTB) ranks 
second among the notifiable infectious diseases prevalent in the area [5], and the Yunnan provincial surveillance system for $\mathrm{TB}$ reported recently that the overall incidence is 56 cases per 100000 population [4]. Moreover, it was noted that TB incidence in some regions were higher than the average reported for the province. Especially the incidence in Zhaotong, a prefecture-level city, accounts for the highest number of PTB cases in Yunnan [6]. Therefore, we deemed it necessary to investigate the determinants that could potentially influence high PTB prevalence in this region.

The spatial distribution of $\mathrm{TB}$ has been widely investigated in China $[7,8]$ and several studies have shown that this infection has a heterogeneous distribution in space and time $[9,10]$. However, information on the risk factors influencing $\mathrm{TB}$ aggregation is scarce [11-13]. PTB is known to be a chronic respiratory infectious disease transmitted from person to person, its distribution is associated with a large variety of factors in the human environment $[14,15]$. Our previous study identified spatio-temporal clusters for the total PTB registration rate in Zhaotong [6], and this study aims to further this research by exploring the particular risk factors, so as to effectively provide both theoretical and technical support for $\mathrm{TB}$ prevention and control in China.

\section{Methods}

\section{Study setting}

The prefecture-level community of Zhaotong has a total population of 5.82 million including 0.54 million of ethnic minorities and covers an area of more than $23000 \mathrm{~km}^{2}$ in north-east Yunnan Province. The terrain is low in the North and mountainous in the South. The lowest land is in Shuifu County (267 m above the mean sea level), while Qiaojia County represents the highest $(4040 \mathrm{~m})$. A total of 143 towns (132 rural towns and 11urban towns) in 11 counties were selected as the study sites.

\section{Recruitment of study subjects}

Patients who had visited the Zhaotong Center for Disease Control (CDC) for PTB diagnosis between October 2015 and February 2016 were selected as the study subjects. PTB patients were consecutively included in the study according to the order of diagnosis.

The inclusion criteria were: (1) having active PTB (according to the new revision of the WS288-2008 [16] diagnostic manual); (2) willingness to participate in the study; and (3) having signed the informed consent form. Exclusion criteria included: (1) inability to cooperate with the investigators due to mental or physical disorders; and (2) refusal to sign the informed consent form for various reasons.

\section{Cluster investigation}

Based on the number of PTB cases registered at the town level in Zhaotong, spatio-temporal analysis was used to identify and locate statistically significant aggregations of registered PTB from 2011 to 2015 in the nationwide $\mathrm{TB}$ online registration system. We applied SaTScan ${ }^{\mathrm{TM}}$ software version 9.4.2 (https:// www.satscan.org/) [17] as described in a previous study by our research group [6]. Furthermore, we divided PTB-diagnosed subjects registered between October 2015 and February 2016 into two groups: (1) cases living within towns identified as having spatial clusters; and (2) cases residing outside identified clusters (the control group). We linked/geo-referenced the location of PTB cases by their home addresses at town-level.

\section{Questionnaire approach}

A structured questionnaire was developed and administered by the trained doctors from 11 county level CDCs engaging subjects in face to face interviews.

The questionnaire was divided into four sections including biological; behavioural; socio-economic and local environmental aspects, each section was further divided into sets of indicators as shown in Table 1 that includes full definitions of all variables investigated.

A total of 1508 PTB cases were investigated and all the questionnaires were completed as requested. All subjects signed the informed consent form and voluntarily participated in the survey.

\section{Data analysis}

EpiData software, version 3.1 (http://www.epidata.dk/) was used to double-check the questionnaire data to avoid double entry. Data were analysed by SPSS version19.0 (https://www.ibm.com/products/ spss-statistics) statistical software. The data were sorted out, then assigned binary variables ( 0 or 1$)$ and transformed into multiple categorical variables by setting dummy variables. The characteristics of the biological, behavioural, socio-economic and environmental factors between PTB cases within and outside the spatial cluster identified were compared. Univariate logistic regression analysis was carried out and variables found to be significant were entered into a multivariate logistic regression model to analyse the association of factors of PTB spatial aggregation. The level indicating statistical significance for all analyses was set at 0.05 . 
Table 1 Investigated potential indicators of PTB in Zhaotong

\begin{tabular}{|c|c|c|c|}
\hline Biological aspects & Behavioural aspects & Socio-economic aspects & Local environment aspects \\
\hline$\overline{\mathrm{Age}^{\mathrm{a}}}$ & Alcohol intake $e^{e}$ & Annual family income (yuan) ${ }^{k}$ & Residence location $^{p}$ \\
\hline Gender $^{\mathrm{b}}$ & Chronic fatigue or overwork ${ }^{f}$ & Below poverty level $^{c}$ & Family size ${ }^{q}$ \\
\hline BCG vaccination ${ }^{c 1}$ & Frequent Internet café visits ${ }^{c}$ & CDC (km from residence) $)^{\prime}$ & Number of persons per room ${ }^{r}$ \\
\hline $\mathrm{BMI}^{\mathrm{d}}$ & Marital status ${ }^{\mathrm{g}}$ & CDC (minutes from residence) $)^{m}$ & Living space per person ${ }^{5}$ \\
\hline Hormone therapy ${ }^{c}$ & Migrant work ${ }^{c}$ & Educational level $^{n}$ & Windows per $\mathrm{m}^{2}$ of family space ${ }^{t}$ \\
\hline Cancer $^{c}$ & Smoking (active) ${ }^{\mathrm{h}}$ & Health insurance ${ }^{c 1}$ & Frequently keeping windows open ${ }^{\mathrm{c}}$ \\
\hline Chronic bronchitis $^{c}$ & Smoking (passive) ${ }^{i}$ & Occupation $^{\circ}$ & Coal used for cooking/heating ${ }^{c}$ \\
\hline Diabetes $^{c}$ & Spitting habit ${ }^{c}$ & & Electricity used for cooking/heating ${ }^{c}$ \\
\hline HIV/AIDS ${ }^{c}$ & & & Firewood used for cooking/heating ${ }^{c}$ \\
\hline Kidney disease $e^{c}$ & & & Natural/biogas used for cooking/heating ${ }^{c}$ \\
\hline Mental disease $\mathrm{c}^{c}$ & & & Other energy source for cooking/heating ${ }^{c}$ \\
\hline Parasitic disease $\mathrm{e}^{c}$ & & & PTB patient(s) living nearby ${ }^{c}$ \\
\hline Pneumoconiosis $^{c}$ & & & Contact with PTB patient $(s)^{c}$ \\
\hline Other $^{c}$ & & & \\
\hline
\end{tabular}

Abbreviations: AIDS Acquired immune deficiency syndrome, BMI Body mass index, CDC Zhaotong Center for Disease Control, HIV Human immunodeficiency virus Definitions: ${ }^{\mathrm{a}}<15=1 / 15-29=2 / 30-44=3 / 45-59=4 / \geq 60=5 ;{ }^{\mathrm{b}} \mathrm{male}=1 / \mathrm{female}=0 ;{ }^{\mathrm{c} 1}$ no $=1 /$ yes $=0 ;{ }^{\mathrm{c}}$ yes $=1 / \mathrm{no}=0,{ }^{\mathrm{d}}<18.5=1 / \geq 25=2 / 18.5-24.9=3 ;{ }^{\mathrm{e}}$ never $=1 / \mathrm{in}$ the past $=2 /$ currently $=3 ;{ }^{\mathrm{f}}$ yes (light or heavy $=1 /$ no $=0 ;{ }^{9}$ unmarried $=1 /$ married or remarried $=2 /$ divorced or widowed $=3 ;{ }^{h}$ never $=1 /$ past smoker $=2 /$ current smoker $=3$; ${ }^{i}$ no exposure $=1 /$ light exposure $=2 /$ heavy exposure $=3 ;{ }^{k}<2000=1 / 2000-5000=2 / 5001-10000=3 ;^{\prime} \geq 10001=4<15=1 / 15-30 / 31-60 / \geq 61 ;{ }^{m}<31$ $=1 / 31-60=2 / 61-120=3 / \geq 121 ;{ }^{n}$ primary school or below $=1 /$ middle or technical secondary school $=2 /$ junior college and above $=3 ;{ }^{\circ}$ farmer or migrant worker $=$ 1/other $=2 /$ unemployed $=3 /$ student $=4 ;{ }^{{ }^{p}}$ urban $=1 /$ rural $=0 ;{ }^{~}{ }^{\mathrm{C}}<3=1 / 3-4=2 / 5-6=3 />7=4 ;{ }^{r} \leq 1=1 / 1.6-2=2 />2=3$;

${ }^{\mathrm{s}} \leq 10 \mathrm{~m}^{2}=1 / 11-25 \mathrm{~m}^{2}=2 / 26-50 \mathrm{~m}^{2}=3 />50 \mathrm{~m}^{2}=4 ; \operatorname{tow}(<0.05)=1 /$ medium $(0.05-0.077)=2 /$ high $(>0.077)=3$

\section{Results}

\section{Reported PTB incidence in the study area}

PTB notification rates per 100000 population in Zhaotong were 93.8, 91.4, 96.0, 103.84 and 86.10 , respectively between 2011 and 2015. As shown in Fig. 1, the average of these notification rates (90 per 100000 population over the 5 years) studied exceeded the rate reported for the whole province and, indeed, the entire country.

\section{Spatio-temporal cluster analysis}

Table 2 shows that there were five statistically significant clusters, each with a higher than expected numbers of cases, including one most likely cluster and four secondary ones. Altogether, they covered 38 towns (out of a total of 105) persisting for a long time (March 2013 to August 2015) with the most likely cluster involving 29 towns distributed over a large area of Zhenxiong County. The first secondary cluster

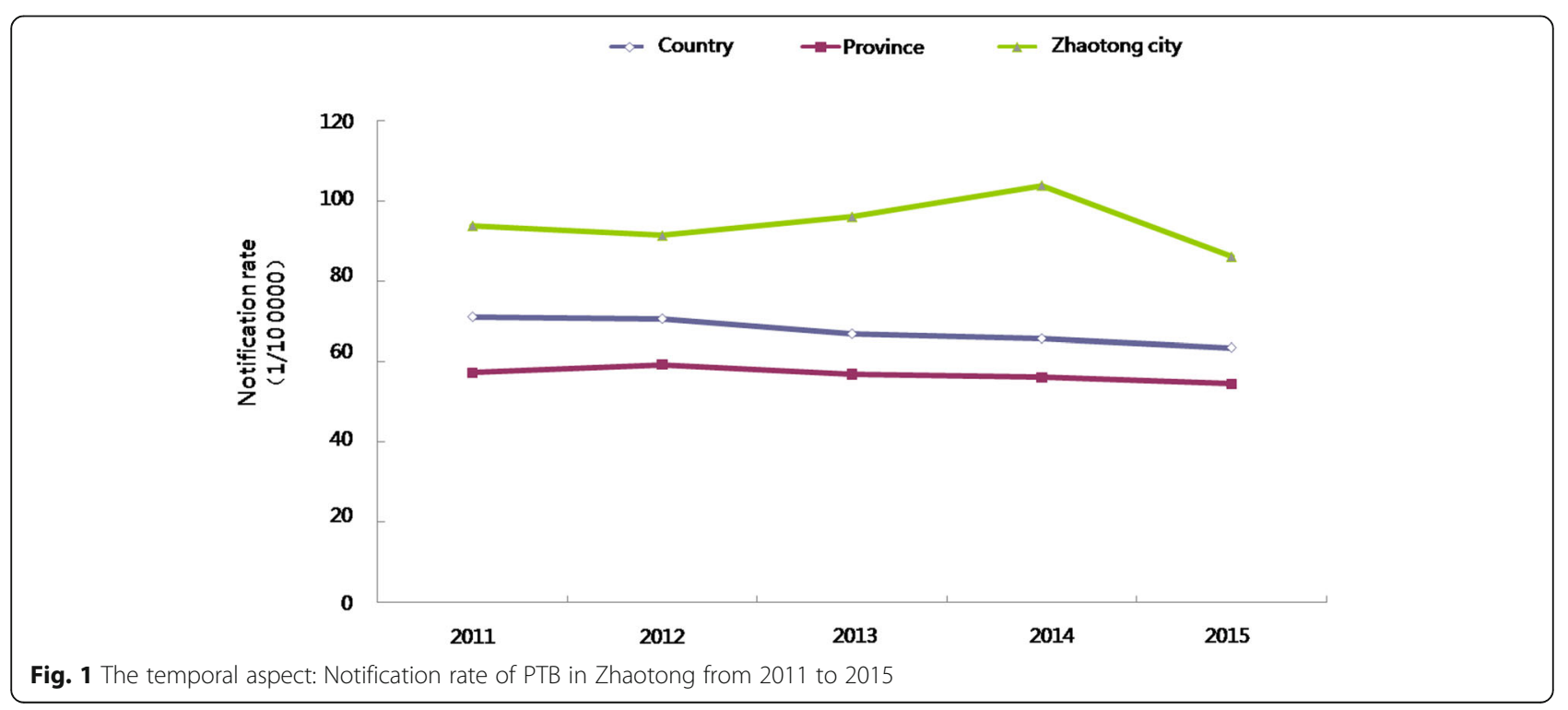


Table 2 Space-time PTB clusters in Zhaotong in the period 2011/1/1-2015/12/31

\begin{tabular}{|c|c|c|c|c|c|c|c|}
\hline Cluster type & Time period & Centre and radius $(\mathrm{km})$ & Areas covered $(n)$ & Observed cases $(n)$ & Expected cases $(n)$ & $\mathrm{RR}^{\mathrm{a}}$ & $P$-value \\
\hline Most likely cluster & $2013 / 3 / 1-2015 / 8 / 31$ & Wufeng 45.51 & 29 & 5994 & 3418 & 2.01 & $<0.001$ \\
\hline Secondary cluster 1 & $2014 / 4 / 1-2014 / 6 / 30$ & Fenghuang 7.06 & 3 & 155 & 45 & 3.47 & $<0.001$ \\
\hline Secondary cluster 2 & $2011 / 2 / 1-2013 / 7 / 31$ & Dousha 13.76 & 3 & 362 & 214 & 1.70 & $<0.001$ \\
\hline Secondary cluster 3 & 2011/3/1-2012/10/31 & Cuihua 0 & 1 & 119 & 58 & 2.06 & $<0.001$ \\
\hline Secondary cluster 4 & 2015/12/1-2015/12/31 & Zhongming 9.04 & 2 & 23 & 6 & 3.91 & 0.030 \\
\hline Secondary cluster 5 & $2012 / 2 / 1-2012 / 5 / 31$ & Xiluodu 17.84 & 4 & 81 & 45 & 1.82 & 0.162 \\
\hline Secondary cluster 6 & $2012 / 1 / 1-2012 / 7 / 31$ & Baihetan 0 & 1 & 86 & 51 & 1.68 & 0.704 \\
\hline
\end{tabular}

Relative risk

involved Fenghuang Town covering three towns from April 2014 to June 2014; the second involved Dousha Town in Yanjin County covering three towns from February 2011 to July 2013; the third covered only one town, namely Cuihua Town and it persisted from March 2011 to October 2012, while the fourth involved Zhongming Town in Yiliang County covering two towns. The last secondary cluster emerged in December 2015 but lasted only for 1 month.

\section{Characteristics of PTB cases within and outside the spatial clusters}

Of the 1508 PTB cases investigated by questionnaire, 1038 were male $(68.8 \%)$ and 470 female (31.2\%). A significant proportion of the cases were found in the age groups $15-29$ years old (> 30\%) and 30-44 years old (around 25\%). The proportion of farmers and migrant workers was $77.2 \%$, students (8.4\%), unemployed (2.9\%), and others (5.9\%). The treatment history showed that a great majority (1474) were receiving initial treatment $(97.8 \%)$ with only 34 cases were under retreatment schedule (2.3\%). More importantly, 813 cases $(53.9 \%)$ of the 1508 subjects resided inside the spatial cluster, while the remaining 695 (46.1\%) lived outside.

\section{Univariate regression analysis \\ PTB and biological factors}

Location was used as the dependent variable with 14 indicators considered as independent variables.

There were no correlation between PTB and cancer and long-term treatment with hormones. However, as seen in Table 3, correlations with the other 12 variables were seen, in particular there were significant findings with regard to age group, BMI value, Bacillus Calmette-Guérin (BCG) vaccination, chronic bronchitis, co-infection with pneumoconiosis, as well as with a variety of other biological complications. Patients with chronic bronchitis, no BCG vaccination and those below 44 years of age had a strong association with PTB.

\section{PTB and behavioural factors}

Location was used as the dependent variable with eight indicators considered as independent variables.
Table 4 shows that there were significant differences in smoking, both active and passive, and history of alcohol intake. There was a particularly strong association between PTB and drinking alcohol as well as smoking, both by the patients and exposure to smoke in everyday life.

\section{PTB and socio-economic factors}

Location was used as the dependent variable with seven indicators considered as independent variables.

Table 5 shows that there were significant PTB associations with family annual income, occupation and the time needed for the patients to reach CDC from their homes. Comparatively higher number of students with PTB were also found in the clustered areas.

\section{PTB and environmental factors}

Location was used as the dependent variable with seven indicators considered as independent variables.

As shown in Table 6, there were significant associations between PTB and place of residence, the type of fuel used for cooking and heating in the household and the amount of living space per person. Patients living in urban areas, using coal for household cooking and heating and a living space per person not more than $10 \mathrm{~m}^{2}$ had higher risk of PTB, while households using electricity for cooking and heating were associated with lower PTB risk.

\section{Multivariate logistic regression analysis}

Table 7 shows that a total of 17 independent variables were statistically significant in univariate logistic regression analyses, and were therefore subsequently entered into the multivariate logistic regression model. The outcome was that a long history of bronchitis $(O R=3.683$, 95\% CI: $2.180-6.223)$, living in an urban area $(O R=5.876$, 95\% CI: 2.38-14.502) and use of coal as the main fuel for domestic use $(O R=9.356,95 \% C I$ : 5.620-15.576) were seen as independently associated with clustering. While a non-smoking habit $(O R=0.340,95 \% C I$ : $0.137-0.843)$, using electricity as the main source for cooking and heating $(O R=0.209,95 \% C I: 0.122-0.359)$ and a BMI below the norm $(O R=0.516,95 \% C I: 0.275-0.968)$ were protective factors. 
Table 3 Univariate analysis of PTB and biological factors

\begin{tabular}{|c|c|c|c|c|c|c|c|c|}
\hline \multirow[t]{2}{*}{ Variable } & \multirow[t]{2}{*}{ Group } & \multicolumn{2}{|c|}{ Outside the cluster } & \multicolumn{2}{|c|}{ Within the cluster } & \multirow[t]{2}{*}{$x^{2}$} & \multirow[t]{2}{*}{$P$-value } & \multirow[t]{2}{*}{$O R(95 \% C l)$} \\
\hline & & No. & $\%$ & No. & $\%$ & & & \\
\hline \multirow[t]{5}{*}{ Age } & $<15$ & 9 & 1.3 & 31 & 3.8 & 12.431 & 0.000 & $4.054(1.862-8.826)$ \\
\hline & $15-29$ & 189 & 27.2 & 291 & 35.8 & 15.395 & 0.000 & $1.812(1.347-2.439)$ \\
\hline & $30-44$ & 164 & 23.6 & 212 & 26.1 & 7.031 & 0.008 & $1.521(1.116-2.075)$ \\
\hline & $45-59$ & 180 & 25.9 & 149 & 18.3 & 0.026 & 0.873 & $0.974(0.708-1.340)$ \\
\hline & $\geq 60$ & 153 & 22 & 130 & 16 & & & 1.000 \\
\hline \multirow[t]{2}{*}{ Gender } & Male & 489 & 70.4 & 549 & 67.5 & 1.400 & 0.237 & $0.876(0.704-1.091)$ \\
\hline & Female & 206 & 29.6 & 264 & 32.5 & & & 1.000 \\
\hline \multirow[t]{2}{*}{ BCG vaccination } & No & 300 & 65.8 & 325 & 76.1 & 11.269 & 0.001 & $1.657(1.234-2.225)$ \\
\hline & Yes & 156 & 34.2 & 102 & 23.9 & & & 1.000 \\
\hline \multirow[t]{3}{*}{ BMI value } & $<18.5$ & 112 & 16.5 & 87 & 11 & 10.062 & 0.002 & $0.612(0.452-0.829)$ \\
\hline & $\geq 25$ & 54 & 7.9 & 50 & 6.3 & 2.359 & 0.125 & $0.730(0.488-1.091)$ \\
\hline & $18.5-24.9$ & 514 & 75.6 & 652 & 82.6 & & & 1.000 \\
\hline \multirow[t]{2}{*}{ Chronic bronchitis } & Yes & 121 & 17.4 & 364 & 44.8 & 121.108 & 0.000 & $3.846(3.025-4.888)$ \\
\hline & No & 574 & 82.6 & 449 & 55.2 & & & 1.000 \\
\hline \multirow[t]{2}{*}{ Diabetes } & Yes & 19 & 2.7 & 14 & 1.7 & 1.761 & 0.184 & $0.623(0.310-1.253)$ \\
\hline & No & 676 & 97.3 & 799 & 98.3 & & & 1.000 \\
\hline \multirow[t]{2}{*}{ HIV/AIDS } & Yes & 3 & 0.4 & 1 & 0.1 & 1.186 & 0.276 & $0.284(0.029-2.737)$ \\
\hline & No & 692 & 99.6 & 812 & 99.9 & & & 1.000 \\
\hline \multirow[t]{2}{*}{ Kidney disease } & Yes & 1 & 0.1 & 4 & 0.5 & 1.214 & 0.271 & $3.431(0.383-30.772)$ \\
\hline & No & 694 & 99.9 & 809 & 99.5 & & & 1.000 \\
\hline \multirow[t]{2}{*}{ Mental disease } & Yes & 2 & 0.3 & 1 & 0.1 & 0.483 & 0.487 & $0.427(0.039-4.716)$ \\
\hline & No & 693 & 99.7 & 812 & 99.9 & & & 1.000 \\
\hline \multirow[t]{2}{*}{ Parasitic infection } & Yes & 0 & 0 & 2 & 0.3 & 0.000 & 0.999 & $0.000(0.000-0.000)$ \\
\hline & No & 588 & 100 & 582 & 99.7 & & & 1.000 \\
\hline \multirow[t]{2}{*}{ Pneumoconiosis } & Yes & 16 & 2.3 & 6 & 0.7 & 5.739 & 0.017 & $0.316(0.123-0.811)$ \\
\hline & No & 679 & 97.7 & 807 & 99.3 & & & 1.000 \\
\hline \multirow{2}{*}{$\begin{array}{l}\text { Other bio-related } \\
\text { complication(s) }\end{array}$} & Yes & 125 & 18 & 69 & 8.5 & 28.942 & 0.000 & $0.423(0.309-0.579)$ \\
\hline & No & 570 & 82 & 744 & 91.5 & & & 1.000 \\
\hline
\end{tabular}

HIV Human immunodeficiency virus, AIDS Acquired immune deficiency syndrome

\section{Discussion}

This study explore the factors influencing the spatial clustering of PTB previously found in this region [6]. We found that the distribution of PTB in Zhaotong is not random, but rather spatially clustered in south-western Zhaotong. To explore the factors influencing spatial clustering and thus be able to evaluate the risk for infection, PTB cases were investigated with regard to residence within and outside the spatial clusters. The finding that chronic bronchitis, living in an urban area, smoking and the use of coal as the main domestic fuel were strongly associated with PTB clustering, interventions should be targeted towards these factors.

Several studies have shown that smoking increases the risk of PTB infection [18, 19], Lin et al. [20] pointed out that smoking is an independent risk factor for PTB, which is not affected by alcoholism and other social factors. Tobacco smoke contains a variety of harmful substances, which can lead to the damage of respiratory epithelial cell cilia, which affects the body's ability of remove inhaled $M$. tuberculosis by the macrophage phagocytosis [20]. Air contamination that arises from dust and chemical fumes produced by coal combustion impair the respiratory tract in a similar way. Chronic respiratory diseases is identified as an associated risk factor to PTB because it reduces the body immune function and breaks down the respiratory defence functions [21]. Indeed, the high incidence of chronic bronchitis in the region can be attributed to the use of coal for family cooking and heating. Findings from this study shows that the use of coal as the main 
Table 4 Univariate analysis of PTB and behaviour characteristics

\begin{tabular}{|c|c|c|c|c|c|c|c|c|}
\hline \multirow[t]{2}{*}{ Variable } & \multirow[t]{2}{*}{ Group } & \multicolumn{2}{|c|}{ Outside the cluster } & \multicolumn{2}{|c|}{ Within the cluster } & \multirow[t]{2}{*}{$x^{2}$} & \multirow[t]{2}{*}{$P$-value } & \multirow[t]{2}{*}{ OR $(95 \% C l)$} \\
\hline & & No. & $\%$ & No. & $\%$ & & & \\
\hline \multirow[t]{3}{*}{ Alcohol intake } & Never & 532 & 76.5 & 651 & 80.1 & 2.853 & 0.091 & $0.697(0.458-1.060)$ \\
\hline & In the past & 126 & 18.1 & 97 & 11.9 & 11.222 & 0.001 & $0.438(0.270-0.710)$ \\
\hline & Currently & 37 & 5.3 & 65 & 8.0 & & & 1.000 \\
\hline \multirow[t]{2}{*}{ Chronic fatigue (overwork) } & Yes & 537 & 77.3 & 653 & 80.3 & 2.100 & 0147 & $1.201(0.937-1.538)$ \\
\hline & No & 158 & 22.7 & 160 & 19.7 & & & 1.000 \\
\hline \multirow[t]{2}{*}{ Frequent visits to Internet cafés } & Yes & 68 & 9.8 & 77 & 9.5 & 0.042 & 0.837 & $0.965(0.684-1.360)$ \\
\hline & No & 627 & 90.2 & 736 & 90.5 & & & 1.000 \\
\hline \multirow[t]{3}{*}{ Marital status } & Unmarried & 134 & 19.3 & 193 & 23.7 & 0.001 & 0.974 & $0.990(0.551-1.779)$ \\
\hline & Married or remarried & 539 & 77.6 & 588 & 72.3 & 1.031 & 0.310 & $0.750(0.430-1.307)$ \\
\hline & Divorced or widowed & 22 & 3.2 & 32 & 3.9 & & & 1.000 \\
\hline \multirow[t]{2}{*}{ Migrant labour history } & Yes & 218 & 31.4 & 269 & 33.1 & 0.507 & 0.476 & $1.082(0.871-1.344)$ \\
\hline & No & 477 & 68.6 & 544 & 66.9 & & & 1.000 \\
\hline \multirow[t]{3}{*}{ Smoking (active) } & Never & 384 & 55.3 & 501 & 61.6 & 0.003 & 0.953 & $0.991(0.722-1.359)$ \\
\hline & In the past & 229 & 32.9 & 204 & 25.1 & 4.976 & 0.026 & $0.676(0.480-0.954)$ \\
\hline & Currently & 82 & 11.8 & 108 & 13.3 & & & 1.000 \\
\hline \multirow[t]{3}{*}{ Smoking (passive) } & None & 104 & 20.4 & 168 & 23.5 & 0.214 & 0.644 & $0.920(0.647-1.309)$ \\
\hline & Light & 312 & 61.2 & 381 & 53.4 & 5.844 & 0.016 & $0.696(0.518-0.934)$ \\
\hline & Heavy & 94 & 18.4 & 165 & 23.1 & & & 1.000 \\
\hline \multirow[t]{2}{*}{ Spitting habit } & Yes & 224 & 32.2 & 285 & 35.1 & 1.337 & 0.248 & $1.135(0.916-1.407)$ \\
\hline & No & 471 & 67.8 & 528 & 64.9 & & & 1.000 \\
\hline
\end{tabular}

source of fuel for cooking in the region has a unique influence on PTB spatial cluster in Zhaotong. The highest number of PTB cases here was registered during our study period, which coincides with a period of low temperatures. The dominant reliance on coal for cooking and heating coupled with other unhealthy indoor activities such as smoking expose the people to air pollution, which is exacerbated in the winter season due to poor ventilation. It has previously been shown that microscopic particulate matter (PM), a complex mixture that forms a critical portion of air pollution which has long been known to increase the risk of morbidity and mortality for many diseases, is strongly correlated with solid fuel usage for cooking and heating [22].

Supporting the reverse proof of air pollution with respect to $\mathrm{PTB}$ infection, our findings have shown that the use of electricity as the main household fuel for cooking and heating is not associated with the development of PTB. This buttress the fact that coal usage as fuel for cooking is unhealthy and increases the risk of PTB infection. Meanwhile, our findings does not indicate that the use of gas by households is a protective factor. This might be as a result of poor access to such means of cooking or heating, which makes it play an insignificant part in the analysis.

Living in urban areas was found to be an independent risk factor for PTB spatial cluster. Several studies from abroad reported similar findings. For example, TB clusters has been reported in surrounding shelters for homeless people in an urban centre at Texas, near a tuberculosis treatment centre in India, in urban and industrial areas of Japan and around major urban centres in Portugal [23]. Urbanization is closely associated with PTB aggregation. While urban areas tend to have many public large places, a large number of urban migrant population with $\mathrm{PTB}$, may play crucial role in spreading the disease [24]. Li Tao et al. [25] reported that the PTB epidemic is mainly distributed in areas with high population density and frequent movement of people. Therefore, it is pertinent to continually strengthen PTB prevention and control programme activities, especially in the urban areas.

Several studies have reported that individuals with a low BMI have a higher risk of being infected with TB than those with normal BMI [26, 27]. This might be due to low cellular immunity, which has 
Table 5 Univariate analysis of PTB and socio-economic factors

\begin{tabular}{|c|c|c|c|c|c|c|c|c|}
\hline \multirow[t]{2}{*}{ Variable } & \multirow[t]{2}{*}{ Group } & \multicolumn{2}{|c|}{ Outside the cluster } & \multicolumn{2}{|c|}{ Within the cluster } & \multirow[t]{2}{*}{$x^{2}$} & \multirow[t]{2}{*}{$P$-value } & \multirow[t]{2}{*}{ OR $(95 \% C l)$} \\
\hline & & No. & $\%$ & No. & $\%$ & & & \\
\hline \multirow{4}{*}{$\begin{array}{l}\text { Annual family income } \\
\text { (yuan) }\end{array}$} & $<2000$ & 183 & 26.3 & 129 & 15.9 & 12.396 & 0.000 & $0.445(0.283-0.698)$ \\
\hline & $2000-5000$ & 295 & 42.4 & 422 & 51.9 & 0.232 & 0.630 & $0.902(0.594-1.371)$ \\
\hline & $5001-10000$ & 176 & 25.3 & 197 & 24.2 & 2.398 & 0.122 & $0.706(0.454-1.097)$ \\
\hline & $\geq 10001$ & 41 & 5.9 & 65 & 8 & & & 1.000 \\
\hline \multirow[t]{2}{*}{ Below poverty level } & Yes & 131 & 19.6 & 147 & 20 & 0.038 & 0.845 & $1.027(0.789-1.335)$ \\
\hline & No & 537 & 80.4 & 587 & 80 & & & 1.000 \\
\hline \multirow[t]{3}{*}{ Educational level } & Primary school and below & 446 & 64.2 & 441 & 54.2 & 1.267 & 0.260 & $0.688(0.359-1.320)$ \\
\hline & Middle school & 233 & 33.5 & 349 & 42.9 & 0.015 & 0.903 & $1.042(0.539-2.015)$ \\
\hline & Junior college and above & 16 & 2.3 & 23 & 2.8 & & & 1.000 \\
\hline \multirow[t]{4}{*}{ Occupation } & Farmer or migrant worker & 583 & 83.9 & 650 & 80 & 12.023 & 0.001 & $0.509(0.347-0.746)$ \\
\hline & Other work & 41 & 5.9 & 54 & 6.6 & 3.335 & 0.068 & $0.601(0.348-1.038)$ \\
\hline & Unemployed & 29 & 4.2 & 17 & 2.1 & 13.577 & 0.000 & $0.268(0.133-0.540)$ \\
\hline & Student & 42 & 6 & 92 & 11.3 & & & 1.000 \\
\hline \multirow[t]{2}{*}{ Medical insurance } & No & 9 & 1.3 & 7 & 0.9 & 0.663 & 0.415 & $0.662(0.245-1.787)$ \\
\hline & Yes & 686 & 98.7 & 806 & 99.1 & & & 1.000 \\
\hline \multirow{4}{*}{$\begin{array}{l}\text { Distance from medical } \\
\text { facility }(\mathrm{km})\end{array}$} & $<15$ & 162 & 23.4 & 222 & 27.5 & 0.693 & 0.405 & $1.129(0.849-1.502)$ \\
\hline & $15-30$ & 150 & 21.7 & 161 & 20 & 0.646 & 0.421 & $0.884(0.655-1.194)$ \\
\hline & $31-60$ & 207 & 29.9 & 213 & 26.4 & 1.361 & 0.243 & $0.848(0.642-1.119)$ \\
\hline & $\geq 61$ & 173 & 25 & 210 & 26.1 & & & 1.000 \\
\hline \multirow{4}{*}{$\begin{array}{l}\text { Time to reach medical } \\
\text { facility (min) }\end{array}$} & $<31$ & 172 & 24.9 & 186 & 23 & 0.455 & 0.500 & $1.103(0.829-1.469)$ \\
\hline & $31-60$ & 148 & 21.4 & 156 & 19.3 & 0.228 & 0.633 & $1.076(0.798-1.450)$ \\
\hline & $61-120$ & 172 & 24.9 & 269 & 33.3 & 11.128 & 0.001 & $1.596(1.213-2.100)$ \\
\hline & $\geq 121$ & 200 & 28.9 & 196 & 24.3 & & & 1.000 \\
\hline
\end{tabular}

been shown to be associated with a low BMI [26].However, our findings do not agree with these reports, which might be as a result of the different classification standard for the BMI normal value. Meanwhile, we used the WHO standard for BMI classification, whose normal range is from 18.5 to 24.9. It might be due to a low proportion of patients with low BMI, such as students infected with $\mathrm{TB}$ and patients under 45 years old who were in the identified clusters compared with the group not in the clusters. Therefore, this subject needs to be explored in-depth before its application.

The relationship between socio-economic situation and TB has a long history. Previous studies confirmed that TB is closely attributed to poverty [18, 25]. Finding from our study showed that households' annual income was only significant in univariate analysis and not in multivariate analysis after adjusting other factors. Firstly, the overall economic situation in Zhaotong is poor on average and the distribution of socio-economic situation in this region appears to be homogenous. Regardless they were within spatial clusters or outside spatial clusters, the PTB patients' family annual income was not particularly high. Secondly, people in urban areas are richer than the rural areas, but have higher PTB rates, and urbanization turns out to be a confounding factor that weakens the relationship between poverty and PTB. In addition, the family annual income may be linked to other confounding factors, such as migrant population, physical exercise, mental stress, etc., thus not significant in the multivariate analysis.

Our study is based on a big sample size and high data quality, but the influencing factors discussed in this paper are not the only factors affecting PTB distribution. Factors that need further exploration are the nutritional status of patients and genetic factors. Firstly, the nutritional status of patients is not only associate with BMI values, but also the intake of various nutrients [28]. The deficiency of vitamin A has been suspected to contribute to PTB development $[29,30]$, while other studies stress the role vitamin D $[31,32]$. Secondly, a number of genes and chromosomal regions that are associated with PTB susceptibility have been identified [27, 30], and they may play an important role in the susceptibility and degree of 
Table 6 Univariate analysis of PTB and local environmental factors

\begin{tabular}{|c|c|c|c|c|c|c|c|c|}
\hline \multirow[t]{2}{*}{ Variable } & \multirow[t]{2}{*}{ Group } & \multicolumn{2}{|c|}{ Outside the cluster } & \multicolumn{2}{|c|}{ Within the cluster } & \multirow[t]{2}{*}{$x^{2}$} & \multirow[t]{2}{*}{$P$-value } & \multirow[t]{2}{*}{ OR $(95 \% C l)$} \\
\hline & & No. & $\%$ & No. & $\%$ & & & \\
\hline \multirow[t]{2}{*}{ Place of residence } & Urban & 46 & 6.6 & 92 & 11.3 & 9.727 & 0.002 & $1.800(1.244-2.605)$ \\
\hline & Rural & 649 & 93.4 & 721 & 88.7 & & & \\
\hline \multirow[t]{4}{*}{ Family size } & $<3$ & 72 & 10.4 & 60 & 7.4 & 2.431 & 0.119 & $0.676(0.414-1.106)$ \\
\hline & $3-4$ & 281 & 40.4 & 306 & 37.6 & 0.389 & 0.533 & $0.884(0.600-1.303)$ \\
\hline & $5-6$ & 286 & 41.2 & 378 & 46.5 & 0.128 & 0.721 & $1.073(0.730-1.576)$ \\
\hline & $>7$ & 56 & 8.1 & 69 & 8.5 & & & \\
\hline \multirow[t]{3}{*}{ Number of persons per room } & $\leq 1$ & 238 & 34.4 & 255 & 32 & 0.907 & 0.341 & $0.886(0.690-1.137)$ \\
\hline & $1.6-2$ & 230 & 33.2 & 271 & 34 & 0.043 & 0.835 & $0.974(0.759-1.250)$ \\
\hline & $>2$ & 224 & 32.4 & 271 & 34 & & & \\
\hline \multirow[t]{4}{*}{ Living space per person $\left(\mathrm{m}^{2}\right)$} & $\leq 10$ & 30 & 4.4 & 62 & 7.9 & 7.199 & 0.007 & $2.606(1.294-5.246)$ \\
\hline & $11-25$ & 371 & 54.6 & 459 & 58.5 & 2.387 & 0.122 & $1.560(0.887-2.742)$ \\
\hline & $26-50$ & 250 & 36.8 & 241 & 30.7 & 0.442 & 0.506 & $1.215(0.684-2.160)$ \\
\hline & $>50$ & 29 & 4.3 & 23 & 2.9 & & & \\
\hline \multirow[t]{3}{*}{ Number of windows per $\mathrm{m}^{2}$ of family space } & Low & 187 & 31.6 & 244 & 37.3 & 0.694 & 0.405 & $1.158(0.820-1.637)$ \\
\hline & Medium & 318 & 53.7 & 313 & 47.8 & 0.649 & 0.420 & $0.874(0.629-1.213)$ \\
\hline & High & 87 & 14.7 & 98 & 15 & & & \\
\hline \multirow[t]{2}{*}{ Frequently keeping windows open } & No & 175 & 25.2 & 203 & 25 & 0.009 & 0.925 & $0.989(0.783-1.249)$ \\
\hline & Yes & 520 & 74.8 & 610 & 75 & & & \\
\hline \multirow[t]{2}{*}{ Coal used for cooking/heating } & Yes & 171 & 24.6 & 651 & 80.1 & 407.611 & 0.000 & $12.314(9.650-15.713)$ \\
\hline & No & 524 & 75.4 & 162 & 19.9 & & & \\
\hline \multirow[t]{2}{*}{ Electricity used for cooking/heating } & Yes & 394 & 56.7 & 125 & 15.4 & 254.639 & 0.000 & $0.139(0.109-0.177)$ \\
\hline & No & 301 & 43.3 & 688 & 84.6 & & & \\
\hline \multirow[t]{2}{*}{ Firewood used for cooking/heating } & Yes & 225 & 32.4 & 287 & 35.3 & 1.431 & 0.232 & $0.877(0.708-1.087)$ \\
\hline & No & 470 & 67.6 & 526 & 64.7 & & & \\
\hline \multirow[t]{2}{*}{ Natural- or biogas used for cooking/heating } & Yes & 14 & 2 & 56 & 6.9 & 17.808 & 0.000 & $3.598(1.985-6.522)$ \\
\hline & No & 681 & 98 & 757 & 93.1 & & & \\
\hline \multirow[t]{2}{*}{ Other energy source for cooking/heating } & Yes & 0 & 0 & 5 & 0.6 & 0.000 & 0.999 & $0.000(0.000-0.000)$ \\
\hline & No & 695 & 100 & 808 & 99.4 & & & \\
\hline \multirow[t]{2}{*}{ PTB patient(s) living nearby } & Yes & 74 & 17.6 & 85 & 19 & 0.266 & 0.606 & $1.095(0.776-1.545)$ \\
\hline & No & 346 & 82.4 & 363 & 81 & & & \\
\hline \multirow[t]{2}{*}{ Contact with PTB patient(s) } & Yes & 70 & 17.9 & 100 & 15.2 & 1.312 & 0.252 & $0.822(0.588-1.149)$ \\
\hline & No & 320 & 82.1 & 556 & 84.8 & & & \\
\hline
\end{tabular}

PTB Pulmonary tuberculosis

PTB severity $[29,33]$. In addition, it is important to note that the number of cases in some of the risk factors group were too small to enable us establish the relationship between these factors and PTB aggregation. However, we plan to use larger sample sizes in our future studies as this would give us the opportunity to have increased number of cases in the risk groups and thus add statistical power to our calculations. Our data may have selection bias because the values of independent variables were PTB patients information and the social demographic variables in each location could be different from the values of PTB cases and general population. Despite these limitations, our study has provided useful information that will improve our understanding on the risk factors of PTB spatio-temporal clustering, not only in north-eastern Yunnan Province but also elsewhere.

\section{Conclusions}

Spatial clustering analysis is an important tool that helps provide aetiological clues. We found PTB specially clustered in south-western Zhaotong. The 
Table 7 Multivariate analysis of the PTB spatial cluster situation

\begin{tabular}{|c|c|c|c|c|c|c|}
\hline Variable & $\beta$ & $S x$ & Wald $x^{2}$ & $P$-value & $a O R$ & $95 \% \mathrm{Cl}$ \\
\hline Age & & & 1.499 & 0.827 & & \\
\hline$<15$ & 0.791 & 0.797 & 0.987 & 0.320 & 2.207 & $0.463-10.513$ \\
\hline $15-29$ & 0.289 & 0.351 & 0.678 & 0.410 & 1.335 & $0.671-2.654$ \\
\hline $30-44$ & 0.311 & 0.342 & 0.825 & 0.364 & 1.365 & $0.698-2.669$ \\
\hline $45-59$ & 0.134 & 0.341 & 0.155 & 0.694 & 1.144 & $0.586-2.232$ \\
\hline$\geq 60$ & & & & & 1.000 & \\
\hline BMI value & & & 5.236 & 0.073 & & \\
\hline$<18.5$ & -0.663 & 0.322 & 4.246 & 0.039 & 0.516 & $0.275-0.968$ \\
\hline$\geq 25$ & -0.494 & 0.396 & 1.555 & 0.212 & 0.610 & $0.281-1.326$ \\
\hline $18.5-24.9$ & & & & & 1.000 & \\
\hline \multicolumn{7}{|l|}{ BCG vaccination } \\
\hline No & 0.063 & 0.283 & 0.049 & 0.825 & 1.065 & $0.612-1.854$ \\
\hline Yes & & & & & 1.000 & \\
\hline \multicolumn{7}{|l|}{ Chronic bronchitis } \\
\hline Yes & 1.304 & 0.268 & 23.757 & 0.000 & 3.683 & $2.180-6.223$ \\
\hline No & & & & & 1.000 & \\
\hline \multicolumn{7}{|l|}{ Pneumoconiosis } \\
\hline Yes & -0.441 & 1.174 & 0.141 & 0.707 & 0.644 & $0.065-6.422$ \\
\hline No & & & & & 1.000 & \\
\hline \multicolumn{7}{|c|}{ Other biology-related complication(s) } \\
\hline Yes & -0.297 & 0.31 & 0.92 & 0.337 & 0.743 & $0.405-1.363$ \\
\hline No & & & & & 1.000 & \\
\hline Alcohol intake & & & 1.767 & 0.413 & & \\
\hline Never & 0.002 & 0.558 & 0 & 0.997 & 1.002 & $0.335-2.993$ \\
\hline In the past & -0.485 & 0.602 & 0.649 & 0.421 & 0.616 & $0.189-2.003$ \\
\hline Currently & & & & & 1.000 & \\
\hline Smoking (active) & & & 5.798 & 0.055 & & \\
\hline Never & -1.08 & 0.464 & 5.418 & 0.020 & 0.340 & $0.137-0.843$ \\
\hline In the past & -1.059 & 0.477 & 4.932 & 0.026 & 0.347 & $0.136-0.883$ \\
\hline Currently & & & & & 1.000 & \\
\hline Smoking (passive) & & & 0.85 & 0.654 & & \\
\hline No exposure & -0.237 & 0.329 & 0.521 & 0.470 & 0.789 & $0.414-1.503$ \\
\hline Light & -0.27 & 0.296 & 0.834 & 0.361 & 0.763 & $0.428-1.363$ \\
\hline Heavy & & & & & 1.000 & \\
\hline Annual family income (yuan) & & & 3.263 & 0.353 & & \\
\hline$<2000$ & -0.377 & 0.485 & 0.604 & 0.437 & 0.686 & $0.265-1.775$ \\
\hline $2000-5000$ & -0.244 & 0.421 & 0.335 & 0.563 & 0.784 & $0.344-1.788$ \\
\hline $5001-10000$ & -0.628 & 0.425 & 2.188 & 0.139 & 0.534 & $0.232-1.227$ \\
\hline$\geq 10001$ & & & & & 1.000 & \\
\hline Occupation & & & 2.382 & 0.497 & & \\
\hline Farmer/migrant worker & -0.506 & 0.421 & 1.441 & 0.230 & 0.603 & $0.264-1.377$ \\
\hline Other & -0.264 & 0.593 & 0.198 & 0.656 & 0.768 & $0.240-2.456$ \\
\hline Unemployed & -0.864 & 0.621 & 1.934 & 0.164 & 0.421 & $0.125-1.424$ \\
\hline Student & & & & & 1.000 & \\
\hline
\end{tabular}


Table 7 Multivariate analysis of the PTB spatial cluster situation (Continued)

\begin{tabular}{|c|c|c|c|c|c|c|}
\hline Variable & $\beta$ & $S x$ & Wald $x^{2}$ & $P$-value & $a O R$ & $95 \% \mathrm{Cl}$ \\
\hline Time to medical facility (min) & & & 3.185 & 0.364 & & \\
\hline$<31$ & 0.55 & 0.346 & 2.53 & 0.112 & 1.733 & $0.880-3.412$ \\
\hline $31-60$ & 0.072 & 0.317 & 0.051 & 0.821 & 1.074 & $0.577-1.999$ \\
\hline $61-120$ & 0.302 & 0.278 & 1.179 & 0.277 & 1.352 & $0.784-2.330$ \\
\hline$\geq 121$ & & & & & 1.000 & \\
\hline \multicolumn{7}{|l|}{ Place of residence } \\
\hline Urban areas & 1.771 & 0.461 & 14.758 & 0.000 & 5.876 & $2.381-14.502$ \\
\hline Rural areas & & & & & 1.000 & \\
\hline \multicolumn{7}{|l|}{ Coal used for cooking/heating } \\
\hline Yes & 2.236 & 0.26 & 73.923 & 0.000 & 9.356 & $5.620-15.576$ \\
\hline No & & & & & 1.000 & \\
\hline \multicolumn{7}{|c|}{ Electricity used for cooking/heating } \\
\hline Yes & -1.564 & 0.275 & 32.247 & 0.000 & 0.209 & $0.122-0.359$ \\
\hline No & & & & & 1.000 & \\
\hline \multicolumn{7}{|c|}{ Natural- or biogas used for cooking/heating } \\
\hline Yes & 1.114 & 0.658 & 2.867 & 0.090 & 3.046 & $0.839-11.058$ \\
\hline No & & & & & 1.000 & \\
\hline Living space per person $\left(\mathrm{m}^{2}\right)$ & & & 1.643 & 0.650 & & \\
\hline$\leq 10$ & 0.787 & 0.661 & 1.415 & 0.234 & 2.196 & $0.601-8.031$ \\
\hline $11-25$ & 0.324 & 0.517 & 0.391 & 0.532 & 1.382 & $0.501-3.810$ \\
\hline $26-50$ & 0.257 & 0.518 & 0.246 & 0.620 & 1.293 & $0.468-3.570$ \\
\hline$>50$ & & & & & 1.000 & \\
\hline
\end{tabular}

BMI Body mass index, BCG Bacillus Calmette-Guérin

strong associated factors influencing the PTB spatial cluster including: the history of chronic bronchitis, living in the urban area, smoking and the use of coal as the main fuel for cooking and heating. Therefore, interventions should be targeted towards these factors.

\section{Additional file}

Additional file 1: Multilingual abstracts in the five official working languages of the United Nations. (PDF $240 \mathrm{~kb}$ )

\section{Abbreviations}

AIDS: Acquired immune deficiency syndrome; aOR: Adjusted odds ratio; BCG: Bacillus Calmette-Guérin; BMI: Body mass index; CDC: Center of Disease Control and Prevention; Cl: Confidence interval; HIV: Human immunodeficiency virus; OR: Odds ratio; PM: Particulate matter; PTB: Pulmonary tuberculosis; RR: Relative risk; TB: Tuberculosis; WHO: World Health Organization

\section{Acknowledgments}

The authors would like to thank the staff of the CDCs involved in this study and all the patients that participated in the study.

\section{Funding}

This study was supported by the National Special Science and Technology Project for Major Infectious Diseases of China (Grant No. 2012ZX10004-220, 2016ZX10004222-006) and the China-UK Global Health Support Programme
(Grant No. GHSP-CS-OP1-01). The Forth Round of Three-Year Public Health Action Plan of Shanghai, China (No. 15GWZK0101, GWIV-29). The funders had no role in the study design, data collection and analysis, decision to publish, or preparation of the paper.

\section{Availability of data and materials}

In order to protect the privacy of PTB cases, we will not share the original copies of information from the database. We would like to share statistical results of this study. If anyone needs these data, please contact the corresponding author for a soft copy.

\section{Authors' contributions}

$\mathrm{LH}$ and S-ZL designed the research and tools, and supervised the study. $\mathrm{LH}$ analysed the data and wrote the paper. $E M A, X-X L, R B$ and $S-Z L$ revised the paper and provided critical comments. LX, J-BX, YR and C-LC revised and approved the final paper and accept accountability for all aspects of the work. All authors approve the paper for publication.

\section{Ethics approval and consent to participate}

This study was a questionnaire based survey and personal identifiers were coded prior to analysis. Therefore ethical consent was not essential.

\section{Consent for publication}

Not applicable.

\section{Competing interests}

The authors declared that they have no competing interests.

\section{Author details}

${ }^{1}$ Yunnan provincial Center for Disease Control and Prevention, Kunming, China. ${ }^{2}$ National Institute of Parasitic Diseases, Chinese Center for Disease 
Control and Prevention, Ruijing Er road 207, Shanghai 200025, China. ${ }^{3}$ National Research Center for Tropical Disease, Shanghai, China. ${ }^{4}$ Key Laboratory of Parasite and Vector Biology, Ministry of Health, Shanghai, China. ${ }^{5}$ WHO Collaborating Center for Tropical Diseases, Shanghai, China. ${ }^{6}$ Center for Drug Evaluation, China Food and Drug Administration, Beijing, China. ${ }^{7}$ Ingerod, Brastad, Sweden.

Received: 19 November 2017 Accepted: 30 July 2018

Published online: 17 August 2018

\section{References}

1. World Health Organization: Global Tuberculosis Report 2015. http:// www.tbonline.info/posts/2015/10/28/global-tuberculosis-report-2015/. Accessed 11 Jun 2017.

2. World Health Organization: Global Tuberculosis Report 2016. http://www. who.int/tb /publications/global report/en/. Accessed 17 Jul 2017.

3. Wang LX. Status analysis of tuberculosis prevention and control. China Chin J Public Health. 2012;28:413-4.

4. Chen LY, Pang Y, Ma L, Yang HJ, Ru HH, Yang $X$, et al. First insight into the molecular epidemiology of Mycobacterium tuberculosis isolates from the minority enclaves of southwestern China. Biomed Res Int. 2017; https://doi. org/10.1155/2017/2505172

5. Yunnan CDC. Yunnan Tuberculosis Control Report 2015. In: Kunming. China: Yunnan Centre for Disease Control and Prevention; 2015.

6. Huang L, Li XX, Abe EM, Xu L, Ruan Y, Cao CL, et al. Spatial-temporal analysis of pulmonary tuberculosis in the northeast of the Yunnan province, People's republic of China. Infect Dis Poverty. 2017;6(1):57-67.

7. Wang T, Xue FZ, Chen YL, Ma YB, Liu YX. The spatial epidemiology of tuberculosis in Linyi City, China, 2005-2010. BMC Public Health. 2012;12:885.

8. Liu Y, Li X, Wang W, Li Z, Hou M, He Y, et al. Investigation of space-time clusters and geospatial hot spots for the occurrence of tuberculosis in Beijing. Int J Tuberc Lung Dis. 2012;16(4):486-91.

9. Zaragoza BA, Hernandez TM, Bustamante ML, Medina TI, Jaramillo PJ, Mendoza $M G$, et al. Spatial and temporal distribution of tuberculosis in the state of Mexico. Mexico Sci World J. 2012; https://doi.org/10.1100/2012/570278.

10. Dangisso MH, Datiko DG, Lindtjorn B. Spatio-temporal analysis of smearpositive tuberculosis in the Sidama zone, southern Ethiopia. PLoS One. 2015;10(6):e126369.

11. Tiwari N, Kandpal V, Tewari A. Investigation of tuberculosis clusters in Dehradun city of India. Asian Pac J Trop Med. 2010;2010:486-90.

12. Zhao F, Cheng SM, He GX, Huang F, Zhang H, Xu B, et al. Space-time clustering characteristics of tuberculosis in China, 2005-2011. PLoS One. 2013;8(12):e83605

13. Hassarangsee S, Tripathi N, Souris M. Spatial pattern detection of tuberculosis: a case study of Si Sa Ket Province, Thailand. Int J Environ Res Public Health. 2015;12:16005-18.

14. Ge E, Zhang X, Wang XM, Wei XX. Spatial and temporal analysis of tuberculosis in Zhejiang Province, China, 2009-2012. Infect Dis Poverty. 2016; https://doi.org/10.1186/s40249-016-0104-2.

15. Oren E, Narita M, Nolan C, Mayer J. Neighborhood socioeconomic position and tuberculosis transmission: a retrospective cohort study. BMC Infect Dis. 2014;14:227.

16. Ministry of health of the People's Republic of China. Diagnostic criteria for pulmonary tuberculosis. Beijing: People's Medical Publishing House (PMPH); 2008.

17. Kulldorff M: SaTScanTM User Guide for version 9.4.2. http://www.satscan. org/. Accessed 11 Jun 2017.

18. Wen CP, Chan TC, Chan HT, Tsai MK, Cheng TY, Tsai SP. The reduction of tuberculosis risks by smoking cessation. BMC Infect Dis. 2010;10:156.

19. He Z, Hu G, Zi Q, Tang H, Gong F, Chen S, et al. Risk factors of pulmonary tuberculosis incidence in Guangzhou:a paired case-control study. Chin J Antituberc. 2012:34(7):425-32

20. Lin Y, Liu H. Association between tobacco smoke and tuberculosis infection/incidence of tuberculosis. Chin J Antituberc. 2011;33(3):169-73.

21. Li W, Zhang Y, Xing J, Ma Z, Qu Y, Li X. Factors associated with primary transmission of multidrug-resistant tuberculosis compared with healthy controls in Henan Province. China Infec Dis Poverty. 2015:4(1):14.

22. Mu L, Liu L, Niu R, Zhao B, Shi J, Li Y, et al. Indoor air pollution and risk of lung cancer among Chinese female non-smokers. Cancer Causes Control. 2013;24(3):439-50.

23. Harling G, Castro MC. A spatial analysis of social and economic determinants of tuberculosis in Brazil. Health Place. 2014;25:56-67.
24. Zhu S, Hou Y, Shu W, Zhang G, Nie S, Chen W, et al. Study oil the risk factors of tuberculosis in four cities and provirices in China. Chin J Epidemiol. 2013;34(2):129-32.

25. Li T, He XX, Chang ZR, Ren YH, Zhou JY, Ju LR, et al. Impact of new migrant populations on the spatial distribution of tuberculosis in Beijing. Int J Tuberc Lung Dis. 2011;15(2):163-8.

26. Li B, Wang Z, Tao Liu T, Du W. Meta-analysis of the risk factor of tuberculosis in China. Chin J Health Statistics. 2011;28(5):527-9.

27. Dong B, Ge N, Liu G. Social economical status, behaviors and environment as the risk factors of tuberculosis in Chengdu China. Chin J Epidemiol. 2012;22(2):102-4.

28. Guo HW. nutriology. Beijing: Bejing Science Press; 2000.

29. Wang $H$, Pan J, Zhang T, Ai X. The influence factors of tuberculosis in college students. Chin General Practice. 2007;10(23):2013-5.

30. Cui $X$, Hong Z, Shen Y. A case control study on environmental risk factors of pulmonary tuberculosis in Kunshan. Chin J Antituberc. 2007;29(6):556-8.

31. Rao H, Zhang X, Zhao L, Yu J, Ren W, Zhang X, et al. Spatial transmission and meteorological determinants of tuberculosis incidence in Qinghai Province, China: a spatial clustering panel analysis. Infect Dis Poverty. 2016;5:45.

32. Zhuang B, Yang B. Overview of human hereditary susceptibility on tuberculosis. Chin J Epidemiol. 2008;29(11):1153-5.

33. Ma MJ. Tuberculosis immunity related gene polymorphisms and pulmonary tuberculosis susceptibility. Military Medical Science Academy of the Chinese people's Liberation Army; 2012

\section{Ready to submit your research? Choose BMC and benefit from:}

- fast, convenient online submission

- thorough peer review by experienced researchers in your field

- rapid publication on acceptance

- support for research data, including large and complex data types

- gold Open Access which fosters wider collaboration and increased citations

- maximum visibility for your research: over $100 \mathrm{M}$ website views per year

At $\mathrm{BMC}$, research is always in progress.

Learn more biomedcentral.com/submissions 